\title{
ПРАВОВОЕ РЕГУЛИРОВАНИЕ КАДРОВОГО ОБЕСПЕЧЕНИЯ ФУНКЦИОНАЛЬНОЙ ДЕЯТЕЛЬНОСТИ ПРОКУРАТУРЫ
}

$\mathrm{P}$ ешение задач совершенствования деятельности органов прокуратуры и повышения эффективности прокурорского надзора, как показывают исследования, находятся в зависимости от ряда взаимодействующих факторов социального, организационно-технического, социально-психологического и правого характера. При рассмотрении этой совокупности факторов применительно к кадровому обеспечению функциональной деятельности прокуратуры, существенного внимания заслуживает, на наш взгляд, раскрытие значения правового фактора, который определяет не только цели и содержание, но и принципы организации кадровой работы.

В управленческой науке достаточно и убедительно сказано о том, что управление и право тесно связанные взаимообусловленные явления. Социальное управление осуществляется на основе правовых норм, создающих определенный правовой режим реализации управленческих функций, правопорядок в сфере управления ${ }^{1}$.

Управление кадрами органов прокуратуры как часть социального управления в этом случае также должна основываться на действующих правовых нормах. Оно может быть усовершенствовано за счет общегосударственного и ведомственного нормотворчества.

Выполнение задач, установленных законом, и успешная реализация полномочий прокуроров зависят от точного закрепления принципов устройства и организации всей системы органов прокуратуры.

Исходя из понимания прокурорского надзора как системы правовых норм, определяющих устройство, организацию и деятельность прокуратуры, правоотношения, которые образуются при применении норм о назначении на должность, аттестации, поощрениях и дисциплинарной ответственности прокуроров, являются правоотношениями внутри системы прокуратуры и носят организационно-правовой характер. Правоотношения, возникающие внутри или вне прокурорской системы в процессе осуществления хозяйственно-административных функций, регулируются нормами других отраслей права (трудового, административного и др.) $)^{2}$.

\footnotetext{
1 См.: Козлов Ю.М., Фролов Е.С. Научная организация управления и право. - М., 1986. - С. 98.

2 См.: Березовская С.Г. Сущность и основные характеристики правовых отношений в сфере прокурорского надзора // Вопросы теории и практики прокурорского надзора. - М., 1989. - С. 69.
}

Таким образом, совокупность правовых норм, регламентирующих порядок прохождения службы в органах прокуратуры и организацию работы с кадрами, является органической составной частью правового регулирования организации и деятельности прокуратуры. В то же время правовые акты, регулирующие действующую в органах прокуратуры систему отбора, расстановки, закрепления и воспитания кадров, представляют относительно самостоятельную группу.

Обобщение и анализ нормативных материалов по вопросам кадрового обеспечения органов прокуратуры позволяют подразделить исследуемую совокупность норм, исходя из их содержания, на несколько групп:

1. устанавливающие основные задачи организации работы с кадрами и направления совершенствования этой деятельности;

2. определяющие порядок назначения, перемещения и увольнения работников прокуратуры;

3. регламентирующие вопросы отбора и подготовки специалистов для работы в органах прокуратуры;

4. регулирующие организацию воспитания кадров и повышения их квалификации;

5. определяющие порядок аттестации и представления прокурорских работников к присвоению классных чинов;

6. устанавливающие порядок поощрения, а также привлечения к дисциплинарной ответственности;

7. регламентирующие организацию учета кадров в органах прокуратуры.

Перечисленные нормы содержатся в различных юридических актах, которые в совокупности представляют систему, обладающую определенной структурой. Изучение показало, что исследуемая система актов характеризуется двумя основными признаками: во-первых, наличием норм различной степени обобщенности (детализации), регулирующих кадровые вопросы; во-вторых, система актов зависит от характера регулируемых правоотношений, степени важности, которую придает им законодатель ${ }^{3}$.

В настоящее время к числу основных направлений кадровой политики, стратегии работы с кадрами в си-

См.: Мелкумов В.Г. О структуре союзных актов о прокурорском надзоре. В сб.: Совершенствование правового регулирования прокурорского надзора в СССР. - М., 1978. - С. 56. 
стеме прокуратуры следует отнести поиск новых подходов к определению условий повышения эффективности деятельности прокурорских работников и федеральных государственных гражданских служащих, обеспечению высокого уровня профессиональной подготовки, стабильности кадров и необходимой их ротации, последовательному развитию инициативы и творческого начала у работников прокуратуры с ориентацией значимости их вклада в результаты деятельности органов прокуратуры. При этом новизна подходов состоит в совершенствовании форм и методов работы с кадрами, механизма отбора кандидатов на должности работников прокуратуры с учётом характеризующих данных, форм обязательного профессионального психологического обследования кандидатов на должности, обеспечении проверки достоверности представляемых сведений о доходах, об имуществе и обязательствах имущественного характера, а также в повышении требовательности к служебному поведению работников органов прокуратуры. Вместе с тем, повышение требовательности к прокурорским работникам и федеральным государственным гражданским служащим (далее - государственным гражданским служащим) должно одновременно сопровождаться мерами материального и морального стимулирования.

Организация работы с кадрами, как и другие функции управления в органах прокуратуры, должно базироваться на качественной нормативной правовой основе.

К числу важнейших законодательных актов, регламентирующих кадровое обеспечение функциональной деятельности органов прокуратуры, следует отнести Конституцию РФ, в соответствии с которой прокуратура составляет единую централизованную государственную систему с подчинением нижестоящих прокуроров вышестоящим и Генеральному прокурору РФ.

При этом Генеральный прокурор РФ назначается на должность и освобождается от должности Советом Федерации по представлению Президента РФ, а прокуроры субъектов РФ назначаются Генеральным прокурором РФ по согласованию с ее субъектами. Иные прокуроры назначаются Генеральным прокурором РФ.

В соответствии с требованиями Конституции РФ полномочия, организация и порядок деятельности, в том числе и организация кадровой работы, определяется Законом о прокуратуре.

Эти конституционные положения наряду с содержанием разд. 5 Закона о прокуратуре, определяют стратегию развития кадрового потенциала системы прокуратуры РФ, устанавливают порядок назначения на должности прокурорских работников, предусматривают требования, обязательные для принятия многих кадровых решений.
Учитывая, что более детальное рассмотрение этих и других нормативных требований будет осуществлено при анализе основных видов кадровой работы и особенностей прохождения службы в органах и учреждениях прокуратуры, в данном случае имеет смысл кратко охарактеризовать только отдельные составляющие правовых основ управления кадрами в органах прокуратуры.

Прежде всего, следует отметить, что вопросы кадрового обеспечения и прохождения службы в органах и учреждениях прокуратуры тесно взаимосвязаны и, зачастую, трудно провести их разграничение, в том числе и при осуществлении правового регулирования этих отношений.

Не случайно упомянутый 5 раздел Закона о прокуратуре, нормы которого распространяются исключительно на прокурорских работников, именуется «Служба в органах и учреждениях прокуратуры. Кадры органов и учреждений прокуратуры». Очевидно, было бы правильным сохранить подобный подход и при дальнейшем нормотворчестве в рассматриваемых сферах, а также при рассмотрении вопросов о правовой защите и социальной поддержке прокурорских работников.

Именно по такому пути пошли разработчики проектов федеральных законов «О полиции» и «О Следственном комитете Российской Федерации», предусмотрев в каждом для своего ведомства едином законе отдельные главы о правовом положении (статусе) сотрудников, прохождении службы, об их социальной защите.

По смыслу ст. 1 и 40 данного закона служба в органах и учреждениях прокуратуры РФ, составляющих единую федеральную централизованную систему, является федеральной государственной службой. При этом прокурорские работники являются федеральными государственными служащими, исполняющими обязанности по должности федеральной государственной службы с учетом требований Закона о прокуратуре.

Прокуратура России, выступая в качестве государственного органа в механизме осуществления единой государственной власти, относится к числу федеральных государственных органов, правовое оформление организации и деятельности которой осуществляется на принципах государственной службы. По Закону о прокуратуре (ст. 40) служба в органах и учреждениях прокуратуры является видом федеральной государственной службы, а прокурорские работники, т.е. прокуроры, научные и педагогические работники, другие работники органов и учреждений прокуратуры, имеющие классные чины (воинское звание) по своему статусу относятся к федеральным государственным служащим и исполняют обязанности по государственной должности этой службы

4 В соответствии с законодательством о государственной службе в федеральном государственном органе могут быть 
Под государственной службой понимается профессиональная деятельность по обеспечению исполнения полномочий государственных органов. Соответственно согласно Закону о прокуратуре служба в прокуратуре (или как её нередко именуют прокурорская служба), как специальный вид государственной службы - это деятельность прокурорских работников, занимающих соответствующие должности федеральной государственной службы, по реализации полномочий от имени РФ по надзору за соблюдением Конституции РФ и исполнением законов, действующих на ее территории и по выполнению иных функций, установленных законодательством.

Как и иная государственная служба, служба прокурорских работников в органах и учреждениях прокуратуры строится на принципах и условиях, установленных федеральными законами от 27.05.2003 № 58-Ф3 «О системе государственной службы Российской Федерации» ${ }^{5}$ и от 27.07.2004 № 79-Ф3 «О государственной гражданской службе Российской Федерации ${ }^{6}$ с учетом особенностей, предусмотренных Законом о прокуратуре.

К принципам службы в органах и учреждениях прокуратуры следует отнести:

- требование законности, выражающееся в соблюдении Конституции РФ, трудового и другого законодательства, регулирующего деятельность и прохождение службы работниками прокуратуры;

ний к прохождению службы в системе прокуратуры с учётом профессиональной, моральной и возрастной пригодности, безупречности репутации;

- сочетание гласности и конфиденциальности при подборе, расстановке и использовании кадров органов прокуратуры и при осуществлении ими государственной службы;

- профессионализм и компетентность прокурорских работников, предполагающие высокую степень выполнения обязанностей по должности и достаточный объем знаний, умений и навыков для успешной реализации функциональных обязанностей;

учреждены должности государственной службы различных видов. В настоящее время в органах прокуратуры учрежден перечень должностей только государственной гражданской службы. Принадлежность остальных должностей федеральной государственной службы (прокуроров, их заместителей и помощников и др.) к конкретному виду государственной службы не определена.

5 СЗ РФ. - 2003. - № 22. - Ст. 2063; - № 46 (ч. 1). - Ст. 4437; 2006. - № 29. - Ст. 3123.

6 СЗ РФ. - 2004. - № 31. - Ст. 3215; - 2006. - № 6. - Ст. 636.
- внепартийность службы;

- стабильность и ротацию кадров прокуратуры в сочетании с правом на продвижение по службе по результатам труда с учетом способностей и квалификации.

Важное значение в определении принципов прохождения службы прокурорскими работниками (как и иных государственных служащих) имеет Указ Президента РФ от 12.08.2002 № 885 «Об утверждении общих принципов служебного поведения государственных служащих» ${ }^{7}$. в нем, в частности, указано, что государственный служащий призван:

- воздерживаться от поведения, которое могло бы вызвать сомнение в объективном исполнении должностных (служебных) обязанностей, а также избегать конфликтных ситуаций, способных нанести ущерб его репутации или авторитету государственных органов;

- при возникновении конфликта интересов - ситуации, когда личная заинтересованность влияет или может повлиять на объективное исполнение должностных (служебных) обязанностей - сообщать об этом непосредственному руководителю и выполнять его решение, направленное на предотвращение или урегулирование данного конфликта интересов;

- воздерживаться от публичных высказываний, суждений и оценок в отношении деятельности государственных органов, их руководителей, если это не входит в его должностные (служебные) обязанности и др.

К основам службы в органах и учреждениях прокуратуры, характеризующим ее сущность, относятся такие элементы, как правовое положение прокурорских работников, поступление на службу, условия службы, а также прекращение службы.

Правовой статус прокурорских работников представляет собой совокупность прав, свобод, обязанностей, ограничений, запретов, установленных законодательством и гарантированных государством.

Закон о прокуратуре по объему прав и обязанностей разграничивает несколько групп прокурорских работников:

- прокуроры (в их число входят заместители прокуроров, помощники по особым поручениям, старшие помощники и помощники прокуроров и др.);

- военные прокуроры, их заместители и помощники и др.;

образовательных учреждений прокуратуры; руководители и другие работники этих учреждений,

СЗ РФ. - 2002. - № 33. - Ст. 3196. 
непосредственно занятые научной и преподавательской деятельностью;

- другие работники органов и учреждений прокуратуры, имеющие классные чины (воинские звания). Кроме прокурорских работников, в системе прокуратуры проходят службу государственные гражданские служащие, чьи должности включены в Реестр должностей федеральной государственной службы, утвержденный Указом Президента РФ от 31.12.2005 № 1574 и военнослужащие. На этих работников требования Закона о прокуратуре о прохождении службы не распространяется и их правовой статус определяется соответственно законодательством о государственной гражданской службе и законами о воинских обязанностях и военной службе.

В общем виде наименования должностей прокурорских работников приведены в Законе о прокуратуре и в принятых на его основании нормативных правовых актах, регулирующих различные аспекты деятельности органов и учреждений прокуратуры (например, постановления Правительства РФ от 12.08.1994 № 942 «О порядке исчисления выслуги лет, назначения и выплаты пенсий работникам органов и учреждений прокуратуры Российской Федерации и их семьям» и от 30.07.2005 № 467 «Об установлении должностных окладов прокурорских работников органов прокуратуры Российской Федерации» (в редакции постановления Правительства РФ о 28.05.2008 № 402). Перечень должностей федеральной государственной гражданской службы в органах прокуратуры РФ определён Указом Президента РФ от 31.12.2005 № 1574 «О Реестре должностей федеральной государственной гражданской службы» (раздел 17 Реестра). Более детально (с указанием наименования органа или учреждения прокуратуры и подразделения, в котором замещается должность) наименования должностей прокурорских работников и гражданских служащих указаны в организационно-распорядительных документах органов и учреждений прокуратуры, определяющих их структуру и штатное расписание.

Кроме Закона о прокуратуре, кадровая работа в органах и учреждениях прокуратуры, как указывалось, регламентируется законодательством РФ о государственной гражданской службе, об образовании, трудовым и иным законодательством.

Одним из путей совершенствования кадрового обеспечения функциональной деятельности прокуратуры является четкое определение требований, которым должны соответствовать прокурорские работники различных категорий. Закрепление в законе требований, отражающих общие и специальные принципы подбора кадров прокуратуры, не исключает, а предполагает детализацию этих требований применительно к конкретно занимаемой работником должности.
В п. 2 ст. $40^{1}$ Федерального закона «О прокуратуре Российской Федерации» определены условия, при которых лицо не может быть принято на службу в органы и учреждения прокуратуры (например, если оно имеет гражданство иностранного государства, имело или имеет судимость, признано решением суда недееспособным или ограниченно дееспособным, лишено решением суда права занимать государственные должности государственной службы в течение определенного срока, имеет заболевание, которое согласно медицинскому заключению препятствует исполнению им служебных обязанностей).

Основными требованиями к лицам, претендующим к отбору на должности прокуроров (п. 1 ст. 40 Федерального закона «О прокуратуре Российской Федерации»), являются: а) наличие гражданства РФ; б) наличие высшего юридического образования, полученного в образовательных учреждениях высшего профессионального образования, имеющих государственную аккредитацию; в) способность по состоянию здоровья исполнять возлагаемые служебные обязанности; г) обладание необходимыми профессиональными и моральными качествами. При этом законом допускается возможность назначения в исключительных случаях на должности помощников прокуроров районов, городов и приравненных к ним прокуроров лиц, обучающихся по юридической специальности в образовательных учреждениях высшего профессионального образования, имеющие государственную аккредитацию, и окончившие третий курс указанных образовательных учреждений.

Предъявляемые к лицам, претендующим к отбору на должности прокуроров, требования с необходимостью должны быть по своему содержанию объективными, однако это не совсем соответствует действительности.

Проведение государственной политики, направленной на повышение качества и эффективности функционирования прокуратуры предполагает возрастание требований, которым должны соответствовать прокурорские работники, в том числе к уровню их профессиональной подготовки и личностным качествам.

Современный подход к формированию кадрового пространства, комплектованию его людьми, в максимальной степени отвечающими высоким требованиям статуса прокурорского работника, диктует необходимость перехода от субъективно-личностной оценки к научно-обоснованному профессиональному отбору кандидатов.

Как справедливо отмечает В.Б. Ястребов, самый надежный результат может дать только проверка качеств кандидата практикой, а система профессионального отбора должна начинать действовать с мо- 
мента поступления абитуриента в высшее учебное заведение ${ }^{8}$.

Справедливо и утверждение профессора Скуратова Ю.И. о необходимости развития системы организационных форм, обеспечивающих получение и поддержание квалификации прокурорских работников в состоянии, отвечающем потребностям выполнения возложенных на прокуратуру задач .

В международной практике первые упоминания об использовании объективных критериев при приеме на должности прокуроров сформулированы в Рекомендации Комитета министров Совета Европы от 06.10.2000 N R (2000) 19 «Комитет министров - государствам-членам о роли прокуратуры в системе уголовного правосудия» ${ }^{10}$.

В соответствии с п. b ст. 5 указанной Рекомендации, профессиональная деятельность прокуроров, их продвижение по должностям и перемещение по службе осуществляются в соответствии с известными и объективными критериями, такими как компетентность и опыт.

Несмотря на то, что само понятие «объективные критерии» в указанной Рекомендации не раскрывается, изучением пояснительной записки к данному документу установлено, что они являются гарантией беспристрастности, которая тем или иным образом должна руководить набором и продвижением по службе прокуроров. Организация профессионального набора по конкурсу и создание Комиссий по вопросам службы для судейского корпуса или специально для прокуроров представляют собой некоторые из способов, способствующих достижению беспристрастности. Решения об их переводе с одной должности на другую должны основываться на действительных потребностях службы (с учетом навыков и опыта прокуроров), а не просто исходя из произвольных решений властей. Требования мобильности, однако, не должны приводить к каким бы то ни было приоритетным наборам или назначениям, которые могут иметь разрушительные последствия.

Так, опыт Нидерландов и ФРГ показывает, что механизмами объективного отбора кандидатов на должность прокуроров являются: длительные (до 18 месяцев) стажировки кандидатов на занятие прокурорской должности после окончания вузов,

\footnotetext{
8 Ястребов В.Б. Прокурорский надзор. - М.: Городец, 2001. C. 374 .

9 Скуратов Ю.И. Управление и кадровая политика в прокуратуре как предмет научных исследований // Проблемы кадровой работы в органах прокуратуры. Сборник научных трудов. - М., 1994. - С. 4.

10 Текст Рекомендации опубликован в «Журнале российского права». - 2001. - № 8.
}

включающие тестирование, психологическую диагностику, собеседование, а также дополнительное обучение по системе RAIO в течение 4-6 лет. Особенно тщательно организуются и проводятся конкурсы на занятие должности прокурора. Порядок проведения стажировок, дополнительного обучения, конкурсов па занятие должности прокурора, а также повышения их квалификации регламентируется в нормативных актах министерств юстиции указанных государств ${ }^{11}$.

В этой связи необходимо отметить, что и для России институт стажировок не является новшеством.

Так, в 1934 г. было созвано первое Всесоюзное совещание судебно-прокурорских работников, которое, В частности, выработало требования к кандидатам на прокурорские должности. Вот эти требования: на должность районного прокурора назначаются лица со стажем следственной или судебной работы; при назначении на эту должность лиц со стажем общественной и политической работы, но не знакомых с работой следователя, они обязаны в течение определенного срока овладеть техникой следственного дела или пройти следственный минимум. На прокурорские должности в областной прокуратуре назначались лишь лица, имеющие не менее одного года стажа, а на должности помощников областного прокурора - не менее трех лет стажа такой работы. На должности прокурора прокуратуры республики назначались лица со стажем работы не менее одного года в качестве областного прокурора, его заместителя или помощника.

XVII съезд ВКП(б) признал необходимым ввести технический минимум знаний для каждого руководящего советского работника. НКЮ РСФСР в сентябре 1934 г. в целях повышения квалификации и проверки правовой подготовки оперативных работников прокуратуры, следствия, суда установил обязательную сдачу юридического минимума по утвержденной НКЮ программе. Наркомюст исходил из того, что усвоение юридического минимума означало, что сдавший его практический работник вполне пригоден для занятия должности и успешного выполнения функций прокурора, следователя, судьи ${ }^{12}$.

Изменившиеся условия жизни России продемонстрировали эффективность такого инструмента подбора и расстановки кадров, как конкурсный отбор и сдача квалификационного экзамена. Сегодня подобная практика действует в отношении судей, адвокатов, нотариусов.

\footnotetext{
11 Казарина А. Как обучают прокуроров в Германии и Нидерландах // Законность. - 2000. - № 6. - С. 54-57.

12 Панкратов А.С. Кадры советской прокуратуры // На страже советских законов. - М., 1972. - С. 142-143.
} 
Так, в соответствии с положениями Закона РФ от 26.06.1992 № 3132-I «О статусе судей в Российской Федерации» отбор кандидатов на должность судьи осуществляется на конкурсной основе. В качестве обязательного условиядопускапретендента кконкурсуназамещениевакантной должности судьи установлена сдача квалификационного экзамена на должность судьи, цель которого установить наличие у претендента профессиональных знаний, необходимых для работы в суде определенного вида и уровня. Квалификационный экзамен на должность судьи принимает экзаменационная комиссия. Согласно п. 2 ст. 14 Закона о Судебном департаменте при ВС РФ организация и обеспечение работы экзаменационной комиссии по приему квалификационного экзамена на должность судьи входит в полномочия управления (отдела) Судебного департамента при ВС РФ в соответствующем субъекте РФ. Гражданин, который соответствуют предъявляемым Законом требованиям к кандидатам на должность судьи (достижение возраста 25 лет; наличие высшего юридического образования, стажа работы по юридической профессии не менее пяти лет, отсутствие судимости либо уголовного преследования, гражданства иностранного государства либо вида на жительство или иного документа, подтверждающего право на постоянное проживание гражданина РФ на территории иностранного государства; не признанный судом недееспособным или ограниченно дееспособным; не состоящий на учете в наркологическом или психоневрологическом диспансере; не имеющий иных заболеваний, препятствующих осуществлению полномочий судьи) и который сдал квалификационный экзамен на должность судьи, вправе обратиться в соответствующую ККС с заявлением о рекомендации его на вакантную должность судьи (другими словами, право принять участие в конкурсе на замещение вакантной должности судьи).

Кроме того, в числе требований, предъявляемых в соответствии со ст. 40 Федерального закона «О прокуратуре Российской Федерации» к лицам, назначаемым на должности прокуроров, установлена норма о наличии высшего юридического образования, полученного в образовательном учреждении высшего профессионального образования, имеющем государственную аккредитации. Содержащееся в Законе о прокуратуре понятие образовательного учреждения высшего профессионального образования по сути охватывает такие виды высших учебных заведений, как федеральный университет, университет, академия, институт. В ст. 9 Федерального закона «О высшем и послевузовском профессиональном образовании» определен ряд признаков, в том числе отличающих каждый из этих видов высших учебных заведений. Вместе с тем, единые подходы к качеству осуществляемого в этих учебных заве- дения образовательного процесса достигаются за счет действия федеральных государственных образовательных стандартов высшего профессионального образования, которые в силу ст. 5 Закона о высшем и послевузовском профессиональном образовании предназначены для обеспечения единств образовательного пространства РФ; качества высшего профессионального образования; основы для объективной оценки деятельности образовательных учреждений, реализующих образовательные программы высшего профессионального образования; признания и установления эквивалентности документов иностранных государств о высшем профессиональном образовании.

В связи с присоединением Российской Федерации к Болонскому процессу которым предусмотрено сближение и гармонизация систем образования в Европе целью создания единого пространства высшего образования, основанного на нескольких циклах обучения, в статье 6 Закона о высшем и послевузовском профессиональном образовании установлены следующие уровни высшего профессионального образования:

высшее профессиональное образование, подтверждаемое присвоением лицу, успешно прошедшему итоговую аттестацию, квалификации (степени) «бакалавр»-бакалавриат (со сроком обучения по очной форме четыре года);

высшее профессиональное образование, подтверждаемое присвоением лицу, успешно прошедшему итоговую аттестацию, квалификации (степени) «специалист (со сроком обучения по очной форме не менее пяти лет) или квалификации (степени) «магистр» (со сроком обучения по очной форме два года).

Согласно данной норме Закона лица, получившие документы государственного образца о соответствующем уровне высшего профессиональной образования, подтверждаемого присвоением лицу квалификации (степени «бакалавр», имеют право продолжить на конкурсной основе обучение по образовательной программе высшего профессионального образования - программа магистратуры. При этом квалификация (степень) «бакалавр», квалификации (степень) “специалист» и квалификация (степень) «магистр» при поступлении на работу дают гражданину право претендовать на занятие должности, для которой квалификационными требованиями предусмотрено высшее профессиональное образование, если иное не установлено федеральными законами.

Уместно отметить, что нет единой точки зрения по вопросу о соответствии данному требованию наличия квалификации (степени) «бакалавр», однако споры ведутся о праве лиц, имеющих указанную степень, на занятие должности судьи. Так, в письме Минобразования России от 01.09.2003 N 14-52-1018ин/15 отмечалось, 
что не усматривается препятствий для назначения на должность судьи лица, которому присвоена степень бакалавра юриспруденции и соответствующего требованиям, предъявляемым к кандидату на должность судьи Конституцией РФ и иными законодательными актами РФ ${ }^{13}$. Высшая квалификационная коллегия судей РФ Выразила противоположную точку зрения: квалификация «бакалавр юриспруденции» дает гражданину при поступлении на работу право на занятие должности, для которой квалификационными требованиями предусмотрено высшее профессиональное образование, однако не для назначения на должность судьи (п. 20 разъяснений и рекомендаций Высшей квалификационной коллегии судей РФ от 18.03.2004) ${ }^{14}$.

На наш взгляд, квалификация «бакалавр юриспруденции» является лишь первой ступенью высшего юридического образования, недостаточной для назначения и на должность прокурорского работника, что должно найти свое правовое выражение и одним из способов решения этого вопроса может стать учреждение в органах прокуратуры районного звена должности помощников прокурорского работника, которые могли бы замещать лица, получившие специальность «бакалавр юриспруденции».

Отсюда с необходимостью следует вывод об исключении из ч. 1 ст. 40ำ Федерального закона «О прокуратуре Российской Федерации» положения о том, что на должности помощников прокуроров прокуратур районов, городов и приравненных к ним прокуратур в исключительных случаях могут назначаться лица, обучающиеся по юридической специальности в образовательных учреждениях высшего профессионального образования, имеющих государственную аккредитацию, и окончившие третий курс указанных образовательных учреждений.

Необходимо также отметить, что не определен и другой критерий отбора на работу в органы прокуратуры - состояние здоровья. Как известно, специальных требований к состоянию здоровья прокурорских кадров нет. При приеме на работу в органы прокуратуры кадровые службы исходят из собственного представления о важности тех или иных характеристик здоровья. Общепринято, что не принимаются на работу лица, имеющие психические отклонения, а также физические недостатки, препятствующие выполнению работы в качестве прокурора.

Между тем, в соответствии с положениями ст. 4.1. Закона РФ от 26.06.1992 № 3132-І «О статусе судей в Российской Федерации», для подтверждения от-

13 Бюллетень Минобразования РФ. - 2003. - № 11.

14 Российская юстиция. - 2004. - № 5. сутствия у претендента на должность судьи заболеваний, препятствующих назначению на должность судьи, проводится его предварительное медицинское освидетельствование. Перечень заболеваний, препятствующих назначению на должность судьи, утвержден постановлением Совета судей РФ от 26.12.2002 № 78 на основании представления федерального органа исполнительной власти в области здравоохранения. Форма документа, свидетельствующего об отсутствии заболеваний, препятствующих назначению на должность судьи, утверждена приказом Минздрава России от 21.02.2002 № 61.

Вопрос о заболеваниях, препятствующих исполнению служебных обязанностей прокурорскими работниками, пока не получил должного нормативного закрепления, в связи с чем Генеральной прокуратурой РФ совместно с Минздравсоцразвития России и другими заинтересованными ведомствами в настоящее время прорабатывается вопрос об определении перечня соответствующих заболеваний. Перечень заболеваний, препятствующих поступлению на государственную гражданскую службу РФ или ее прохождению, утвержден приказом Минздравсоцразвития России от 14.12.2009 № 984н.

Обязательным условием для назначения на должности прокурорских работников и гражданских служащих в органах прокуратуры является готовность кандидатов соблюдать ограничения, запреты и обязанности, установленные Федеральным законом «О противодействии коррупции» и другими федеральными законами. Среди них: обязанность представлять сведения о доходах, об имуществе и обязательствах имущественного характера; уведомлять об обращениях в целях склонения к совершению коррупционных правонарушений; принимать меры по недопущению любой возможности возникновения конфликта интересов; запрет на совмещение своей основной деятельности с иной оплачиваемой или безвозмездной кроме преподавательской, научной и иной творческой деятельности, на вхождение в состав органов управления, попечительских или наблюдательных советов, иных органов иностранных некоммерческих неправительственных организаций и действующих на территории России их структурных подразделений, если иное не предусмотрено международным договором РФ или российским законодательством.

Изучением Федерального закона от 28.12.2010 № 403-Ф3 «О Следственном комитете Российской Федерации» установлено, что условия, определенные в ч. 4 ст. 16 указанного закона, препятствующие принятию на службу в Следственный комитет, более содержательны и развернуты в сравнении с теми, которые нашли отражение в Законе о прокуратуре. 
Так, гражданин не может быть принят на службу в Следственный комитет, если он был осужден за преступление по приговору суда, вступившему в законную силу, имеет судимость либо имел судимость, которая снята или погашена, в отношении его осуществляется уголовное преследование либо прекращено уголовное преследование за истечением срока давности, в связи с примирением сторон, вследствие акта об амнистии или в связи с деятельным раскаянием; имеет заболевание, препятствующее поступлению на службу в Следственный комитет или ее прохождению и подтвержденное заключением медицинского учреждения, данным в порядке, определенном Правительством РФ; вышел из гражданства РФ; представил подложные документы или заведомо ложные сведения при поступлении на службу в Следственный комитет; не представил установленные сведения или представил заведомо ложные сведения о своих доходах, об имуществе и обязательствах имущественного характера, а также о доходах, об имуществе и обязательствах имущественного характера супруга (супруги) и несовершеннолетних детей; не соблюдал ограничения и не исполнял обязанности, установленные Федеральным законом от 25.12.2008 № 273-Ф3 «О противодействии коррупции».

Кроме того, этим же законом определено, что указанные требования распространяются также при принятии на должности федеральной государственной гражданской службы и на работу в Следственный комитет по трудовому договору.

Существенную помощь в выборе претендента на вакантную должность оказывают результаты выполнения им функций общественного помощника прокурора, которые в настоящее время осуществляют свою деятельность в отдельных прокуратурах субъектов РФ.

Так, в прокуратуре Удмуртии результативно используется институт общественных помощников прокуроров, что позволяет проверить человека на деле прежде чем принять его на службу в органы прокурату$\mathrm{pы}^{15}$. Такой опыт вполне оправдан и нуждается, на наш взгляд, в его повсеместном внедрении. Особенно это должно распространяться на лиц, впервые поступающих на службу в прокуратуру и не имеющих солидного опыта работы по юридической специальности. Лица, проходящие обучение по программе целевой подготовки специалистов для органов прокуратуры должны назначаться на должности общественных помощников в период прохождения ими производственной практики. Это позволит привить им базовые практические навыки, проверить их морально-волевые качества и

15 Зыкин В. Общественные помощники - основной кадровый резерв // Законность. - 2001. - № 6. - С. 22. произвести отбор наиболее достойных для службы в прокуратуре граждан. На должности прокурорских работников будут назначаться лица подготовленные не только теоретически, но и практически.

На основании вышеизложенного, предлагается изложить ст. $40^{1}$ Федерального закона «О прокуратуре Российской Федерации» в следующей редакции:

«1. Прокурорами могут быть граждане Российской Федерации, имеющие высшее юридическое образование квалификации «специалист», «магистр», полученное в образовательном учреждении высшего профессионального образования, имеющем государственную аккредитацию, и обладающие необходимыми профессиональными и моральными качествами, способные по состоянию здоровья исполнять возлагаемые на них служебные обязанности.

2. Лицо не может быть принято на службу в органы и учреждения прокуратуры и находиться на указанной службе, если оно:

- признано недееспособным или ограниченно дееспособным решением суда, вступившим в законную силу;

- было осуждено за преступление по приговору суда, вступившему в законную силу, имеет судимость либо имело судимость, которая снята или погашена, в отношении его осуществляется уголовное преследование либо прекращено уголовное преследование за истечением срока давности, в связи с примирением сторон, вследствие акта об амнистии или в связи с деятельным раскаянием;

- отказывается от прохождения процедуры оформления допуска к сведениям, составляющим государственную и иную охраняемую законом тайну, если исполнение обязанностей по должности федеральной государственной службы, на замещение которой претендует гражданин, или по замещаемой им должности связано с использованием таких сведений;

- имеет заболевание, препятствующее поступлению на службу в органы и учреждения прокуратуры или ее прохождению и подтвержденное заключением медицинского учреждения, данным в порядке, определенном Правительством Российской Федерации;

- состоит в близком родстве или свойстве (родители, супруги, братья, сестры, дети, а также братья, сестры, родители или дети супругов) с работником органа или учреждения прокуратуры, если их служба связана с непосредственной подчиненностью или подконтрольностью одного из них другому;

- вышло из гражданства Российской Федерации; 
- имеет гражданство другого государства (других государств), если иное не предусмотрено международным договором Российской Федерации;

- представило подложные документы или заведомо ложные сведения при поступлении на службу в органы и учреждения прокуратуры;

- не представило установленные сведения или представил заведомо ложные сведения о своих доходах, об имуществе и обязательствах имущественного характера, а также о доходах, об имуществе и обязательствах имущественного характера супруга (супруги) и несовершеннолетних детей;

- не соблюдало ограничения и не исполняло обязанности, установленные законодательством о противодействии коррупции.

2.1. Для подтверждения отсутствия у претендента на должность прокурора заболеваний, препятствующих принятию на службу в органы и учреждения прокуратуры, проводится его предварительное медицинское освидетельствование. Перечень заболеваний, препятствующих назначению на должность прокурора, утверждается федеральным органом исполнительной власти в области здравоохранения по согласованию с Генеральным прокурором Российской Федерации на основании представления. Форма документа, свидетельствующего об отсутствии заболеваний, препятствующих назначению на должность прокурора, утверждается федеральным органом исполнительной власти в области здравоохранения.

3. Лица принимаются на службу в органы и учреждения прокуратуры на условиях трудового договора, заключаемого на неопределенный срок или на срок не более пяти лет.

4. Лица, обучающиеся по юридической специальности в образовательных учреждениях высшего профессионального образования с оплатой обучения Генеральной прокуратурой Российской Федерации, а также прокурорские работники, обучающиеся в очной аспирантуре с сохранением денежного содержания, предусмотренного абзацем вторым пункта 3 статьи 43.4 настоящего Федерального закона, обязаны в соответствии с заключенными с ними договорами проработать в органах или учреждениях прокуратуры не менее пяти лет. При увольнении из органов или учреждений прокуратуры до истечения указанного срока, за исключением случаев увольнения по состоянию здоровья, в связи с призывом на действительную военную службу, увольнения женщины, имеющей ребенка до восьми лет, в связи с ликвидацией органа или учреждения прокуратуры, сокращением численности или штата работников (далее - организационно-штатные мероприятия), указанными лицами полностью возмещаются затраты на их обучение.
5. На должности прокурора города, района, приравненных к ним прокуроров назначаются лица не моложе 25 лет, имеющие стаж работы прокурором не менее трех лет.

На должности прокуроров субъектов Российской Федерации, приравненных к ним прокуроров назначаются лица не моложе 30 лет, имеющие стаж работы прокурором или следователем не менее пяти лет.

Генеральный прокурор Российской Федерации вправе в исключительных случаях назначать на должности прокуроров субъектов Российской Федерации, прокуроров городов, районов, приравненных к ним прокуроров специализированных прокуратур лиц, имеющих опыт работы по юридической специальности на руководящих должностях в органах государственной власти.

6. Требования, установленные частью 2 настоящей статьи, распространяются также при принятии на должности федеральной государственной гражданской службы и на работу в органы и учреждения прокуратуры по трудовому договору».

К числу важнейших стимулирующих норм в области управления кадрами органов прокуратуры следует отнести ст. 44 Федерального закона «О прокуратуре Российской Федерации». Этой нормой определяется материальное и социальное обеспечение прокурорских работников: в частности, денежное содержание прокурорских работников, которое состоит из должностного оклада, доплат за классный чин, за выслугу лет, за особые условия службы, за сложность, напряженность и высокие достижения в службе, процентных надбавок за ученую степень и ученое звание по специальности, соответствующей должностным обязанностям, за почетное звание «Заслуженный юрист Российской Федерации», премий по итогам службы за квартал и год, других выплат, предусмотренных законодательными и иными нормативными правовыми актами РФ. Этим же законом гарантируется пенсионное обеспечение применительно к условиям, нормам и порядку, установленным законодательством РФ для лиц, проходивших военную службу в органах внутренних дел, и их семей.

Особое место в системе нормативных правовых актов, регламентирующих кадровую работу в прокуратуре, отведено указам Президента РФ.

Часть важнейших норм, регламентирующих различные аспекты социальной поддержки прокурорских работников, содержатся в постановлениях Правительства РФ, к примеру, в постановлениях от 12.08.1994 № 942 (в ред. от 21.04.2010) «О порядке исчисления выслуги лет, назначения и выплаты пенсий работникам органов и учреждений прокуратуры Российской Федерации и их семьям», от 28.04.2003 №247 «Об органи- 
зации назначения, перерасчёта размера, выплаты и доставки пенсии за выслугу лет федеральных государственных служащих, ежемесячных доплат к пенсиям отдельным категориям граждан» и другие.

О.Л. Кожевников и В.В. Кравчук подчеркивают, что систему нормативных источников правового регулирования организации и деятельности прокуратуры необходимо дополнить приказами, указаниями и распоряжениями Генерального прокурора РФ, поскольку «...они оказывают непосредственное воздействие на формирование надзорной практики прокуроров» ${ }^{16}$.

Исходя из специфики деятельности и многообразия функций прокуратуры, особенностей службы, вполне логичным является развитость ведомственного нормотворчества, наличие обилия организационно-распорядительных документов, изданных и издаваемых в настоящее время Генеральным прокурором РФ и его заместителями в сфере организации работы с кадрами в органах прокуратуры. Это касается фактически всех видов кадровой работы, начиная с правового регулирования вопросов отбора кандидатов для прохождения обучения в порядке целевой подготовки кадров для прокуратуры РФ, подготовки специалистов и заканчивая отношениями, возникающими в связи с осуществлением учёта, отчётности и ведения делопроизводства при осуществлении работы с кадрами.

В результате анализа и обобщения рассматриваемой совокупности актов определено, что основную группу составляют приказы Генерального прокурора РФ, которые играют важнейшую роль в регулировании организации работы с кадрами, определении ее основных направлений. Соответственно круг вопросов, решаемых в приказах Генерального прокурора РФ довольно широк.

Приказы Генерального прокурора РФ, регламентирующих вопросы кадрового обеспечения, можно систематизировать следующим образом:

- комплексные нормативного характера, издаваемые по основным проблемам организации борьбы с преступностью и укрепления законности, в которых затрагиваются вопросы работы с кадрами;

- отраслевые по организации подбора, расстановки, воспитания и повышения квалификации работников;

- индивидуальные по конкретным вопросам назначения, перемещения работников, применение мер поощрения и дисциплинарной ответственности и т.п.

16 Кожевников О.Л. и Кравчук В.В. Краткие разъяснения к Ф3 «О прокуратуре РФ»: учеб. пособие / под ред. О.Л. Кожевникова. - Екатеринбург, 2001. - С. 11.
Отдельную группу составляют акты, издаваемые Генеральным прокурором РФ, в форме указаний по различным вопросам работы с кадрами, анализ которых показывает, что в указаниях, как правило, содержатся положения и директивного, и информационного характера. В качестве примера можно привести указание Генерального прокурора РФ от 10.08.2001 № 49/6 «Об организации стажировки в Генеральной прокуратуре Российской Федерации».

Немаловажное значение для регламентации организации работы с кадрами в прокуратуре имеют методические рекомендации, издаваемые по различным проблемным вопросам кадровой работы. В соответствии с принципом централизации построения системы прокуратуры эти рекомендации, издаваемые Генеральной прокуратурой РФ, имеют важное значение для повышения качества служебной деятельности работников органов и учреждений прокуратуры.

Наличие значительного количества законодательных и иных нормативных правовых актов, регулирующих кадровое обеспечение прокурорской деятельности, необходимо в установленном порядке с учётом требований законодательства РФ систематизировать и обновлять, что является необходимым условием совершенствования организации работы с кадрами в системе прокуратуры РФ.

Наряду с обязательным формированием качественных правовых основ, управление кадрами в прокуратуре определяется также существующей структурой построения системы органов прокуратуры, состоящей, как правило, из трех звеньев или трех уровней, отличающихся единством и централизацией построения системы этих органов, подчиненностью нижестоящих прокуроров вышестоящим и обусловливается особенностями прохождения ее работниками государственной службы.

Для более полной характеристики юридической природы нормативных актов по кадровым вопросам необходимо отметить, что они обладают общими признаками, свойственными всем актам управления, в частности нормативным актам управления Генерального прокурора РФ. К таким признакам относятся: обусловленность функцией управления, осуществляемой органами, издающими эти акты; их подзаконность; организующий характер; зависимость от предписаний, даваемых вышестоящими органами.

Вместе с тем, нормативным актам по управлению кадрами присущи специфические признаки. В них содержатся предписания, предназначенные для работников прокурорской системы. Эти акты относятся к организации подбора, расстановки и воспитания кадров и касаются деятельности только работников 
прокуратуры. Особенностью актов, регулирующих кадровые вопросы, является то, что они направлены «внутрь» системы органов прокуратуры. Такая направленность объясняется тем, что кадровая работа является частью «внутреннего» управления прокурорской системы. Объектами управляющего воздействия Генерального прокурора РФ являются работники прокуратуры.

На основе изучения практики издания нормативных актов по кадровым вопросам можно сделать вывод о том, что их отличительным признаком является обеспечивающий характер, обусловленность основной конституционной функцией прокуратуры. Работа по подбору, расстановке и воспитанию кадров направлена на обеспечение деятельности прокурорской системы и выполняется в соответствии с общими целями ее функционирования.

Необходимо отметить, что в то время как осуществление прокурорского надзора регламентировано законодательством с различной степенью детализации, выполнение управленческой деятельности внутри системы прокуратуры урегулировано в меньшей степени. Совершенствование форм и методов работы должно найти выражение в повышении роли право- вого регулирования внутриорганизационной деятельности, в том числе и кадрового обеспечения. Применение правовых норм обеспечивает необходимый порядок, нормальное функционирование системы, а, следовательно, способствует улучшению деятельности по укреплению законности и правопорядка.

Исходными установками на пути совершенствования правового регулирования кадрового обеспечения органов прокуратуры могут быть признаны:

1) Совершенствования правовой регламентации вопросов организации работы с кадрами и порядка прохождения службы должно проводиться в соответствии с рекомендациями, разработанными общей теорией права, теорией прокурорского надзора, а также таких отраслей права, как административное и трудовое, теорией управления.

2) В основе разрабатываемых рекомендаций должен лежать анализ отечественной и зарубежной практики применения законодательства о прокурорском надзоре, в частности кадровом обеспечении.

Восполнение пробелов в области правового регулирования будет способствовать улучшению этой деятельности, а, следовательно, совершенствованию прокурорского надзора.

\section{Библиографический список:}

1. Винокуров Ю.Е. Прокурорский надзор. - М., 2013.

2. Настольная книга прокурора / под ред. С.И. Герасимова. - М., 2002.

3. Григоров К.А. Функции и направления деятельности прокуратуры Российской Федерации в современных условиях // «Черные дыры» в Российском законодательстве. - М., 2003.

4. Езерская А.И. Российская прокуратура в системе институтов контрольно-надзорной власти: политико-правовой статус и приоритеты развития // Юристъ-правоведъ. - М., 2009.

5. Звербуль В.К. Перспективы развития прокурорского надзора в правовом государстве. - М., 1990.

6. Казарина А. Как обучают прокуроров в Германии и Нидерландах // Законность. - 2000. - № 6.

7. Капинус О.С. Настольная книга прокурора / под ред. С.Г. Кехлерова и О.С. Капинус. - М., 2012.

\section{References (transliteration):}

1. Vinokurov Yu.E. Prokurorskii nadzor. - M., 2013.

2. Nastol'naya kniga prokurora / pod red. S.I. Gerasimova. - M., 2002.

3. Grigorov K.A. Funkcii i napravleniya deyatel'nosti prokuratury Rossiiskoi Federacii v sovremennyh usloviyah // «Chernye dyry» v Rossiiskom zakonodatel'stve. - M., 2003.

4. Ezerskaya A.I. Rossiiskaya prokuratura v sisteme institutov kontrol'no-nadzornoi vlasti: politiko-pravovoi status i prioritety razvitiya // Yurist'-pravoved'. - M., 2009.

5. Zverbul' V.K. Perspektivy razvitiya prokurorskogo nadzora v pravovom gosudarstve. - M., 1990.

6. Kazarina A. Kak obuchayut prokurorov v Germanii i Niderlandah // Zakonnost'. — 2000. - № 6.

7. Kapinus O.S. Nastol'naya kniga prokurora / pod red. S.G. Kehlerova i O.S. Kapinus. - M., 2012. 